\title{
Preparation and In Vitro Evaluation of Ibuprofen Spherical Agglomerates
}

\section{İbuprofen Küresel Aglomeralarının Hazırlanması ve in Vitro Değerlendirmesi}

\author{
(1) Nagaraju RAVOURU', (1) Subhash Chandra Bose PENJURI2*, (1) Saritha DAMINENI ${ }^{3}$, (1) Raja Lakshmi MUNI', (1) Srikanth Reddy POREDDY² \\ 'Sri Padmavati Mahila Visvavidyalayam, (Women's University), Institute of Pharmaceutical Technology, Tirupati, Andhra Pradesh, India \\ ${ }^{2}$ MNR College of Pharmacy, Department of Pharmaceutics, Sangareddy, Telangana, India \\ ${ }^{3}$ Sultan-ul-Uloom College of Pharmacy, Department of Pharmaceutics, Hyderabad, Telangana, India
}

\begin{abstract}
Objectives: Ibuprofen, an anti-inflammatory drug, is characterized by poor water solubility, which limits its pharmacologic effects. The present work aimed to the study the effect of agglomeration on the micromeritic properties and dissolution of ibuprofen.

Materials and Methods: Ibuprofen agglomerates were prepared by solvent change method using water, dichloromethane and DMSO as poor solvent, bridging liquid and good solvent respectively in the ratio of 57.5:12.5:30. Process variables such as amount of bridging liquid, mode of addition, temperature and stirring rate were optimized.

Results: SEM studies indicate that agglomerates produced were spherical and exhibit irregular shape. X-Ray Powder Diffraction spectra revealed the absence of polymorphism. DSC spectra showed no change in melting point indicating absence of crystal modification. The agglomerates exhibited improved solubility, dissolution rate and micromeritic properties compared to pure drug.

Conclusion: Anti-inflammatory studies were conducted in Wistar strain male albino rats and ibuprofen agglomerates showed more significant activity than the pure drug which may be due to better absorption. Ulcerogenic potential study was carried out for pure ibuprofen and agglomerates. Better ulcerogenic potential was observed in ibuprofen agglomerates treated rats.
\end{abstract}

Key words: Ibuprofen, spherical agglomeration, anti-inflammatory activity, ulcerogenic potential

ÖZ

Amaç: Bir anti-inflamatuvar ilaç olan ibuprofen, zayıf suda çözünürlüğü ile karakterize olup, farmakolojik etkileri sınırlar. Bu çalışmada aglomerasyonun mikromeritik özellikler ve çözünme üzerindeki etkilerinin incelenmesi amaçlanmıştır.

Gereç ve Yöntemler: İbuprofen aglomeraları, su, diklorometan ve zayıf solvent olarak sırasıyla 57.5:12.5:30 oranında sıvı ve iyi çözücü köprü halindeki dimetil sülfoksit kullanılarak çözücü değiştirme yöntemi ile hazırlandı. Köprü sıvısı miktarı, ilave modu, sıcaklık ve karıştırma oranı gibi proses değișkenleri optimize edildi.

Bulgular: Taramalı elektron mikroskobu çalıșmaları, üretilen aglomeraların küresel olduğunu ve düzensiz șekli olduğunu göstermektedir. X-Işın Pudrası Difraksiyon spektrumu polimorfizm yokluğunu ortaya koydu. Diferansiyel tarama kalorimetrisi spektrumu, erime noktasında kristal modifikasyonun yokluğunu gösteren herhangi bir değişiklik göstermedi. Aglomeralar, saf ilaca kıyasla gelişmiş çözünürlük, çözünme hızı ve mikromeritik özellikler sergiledi.

Sonuç: Anti-inflamatuvar çalışmalar Wistar suşu erkek albino sıçanlarında yürütülmüș ve ibuprofen aglomeraları saf ilaca göre daha iyi bir absorpsiyona bağlı olarak daha belirgin bir aktivite gösterdi. Saf ibuprofen ve aglomera için ülserojenik potansiyel çalışması gerçekleştirildi. İbuprofen aglomeraları ile tedavi edilen sıçanlarda daha iyi ülserojenik potansiyel gözlenmiştir.

Anahtar kelimeler: İbuprofen, küresel toplanma, anti-inflamatuvar aktivite, ülserojenik potansiyel

*Correspondence: E-mail: penjurisubhash@gmail.com, Phone: +919848033974 ORCID-ID: orcid.org/0000-0002-9365-0701

Received: 29.01.2017, Accepted: 13.04.2017

-Turk J Pharm Sci, Published by Galenos Publishing House. 


\section{INTRODUCTION}

Tablets are known to be the most popular dosing form of all pharmaceutical preparations for oral route administration because of easy administration by the patient, least content variability, and great precision. Apart from these advantages, the formulation and manufacturing of tablets is the most convenient and easy process. One of important factors that influence the success of tablet formation is the flowability and compressibility of materials. Direct compressibility is one of the best and most economical techniques for manufacturing tablets. This facilitates processing without the need for moisture or heat, and involves a small number of processing steps. However, the technique depends on the flowability, particle size and particle size distribution, bulk density, and the compressibility of the crystalline drug substances..$^{-3}$ Most drugs such as non-steroidal antiinflammatory drugs exhibit poor compressibility and flowability and are not suitable for direct compression. To enhance the flow properties and compressibility of drugs, several methods have been introduced by researchers. In addition to increasing the efficiency of the manufacturing process, it is also important to increase the bioavailability of the drug by improving the solubility of the bulk drug powder. . $^{4-6}$

Spherical crystallization/agglomeration is a novel method to increase the bioavailability of drugs that inherently have poor aqueous solubility. It is a multiple unit process in which crystallization, agglomeration, and spheronization can be performed simultaneously in one step. The resultant crystals have a characteristic shape, therefore, the micromeritic properties such as flowability, packability, and compressibility of the resultant crystals are dramatically improved, thereby direct tabletting or coating is possible without further processing steps like mixing, agglomeration, and sieving. ${ }^{7-9}$

Spherical crystallization/agglomeration is a process of formation of crystal aggregates held together by liquid bridges. The agglomerates are formed by agitating the crystals in a liquid suspension in the presence of a bridging liquid. The bridging liquid should be immiscible in the suspending medium, but capable of cementing the particles to be agglomerated. ${ }^{10}$ This technique can also be exploited to increase solubility, dissolution, and hence bioavailability of poorly soluble drugs." These modifications allow for the practice of more efficient manufacturing methods that could save time and reduce economic risk.

\section{MATERIALS AND METHODS}

\section{Materials}

Ibuprofen was obtained as a gift sample from Granules India, Hyderabad, India. Dimethyl sulfoxide (DMSO) and dichloromethane were procured from Qualigens fine chemicals, Chennai, India and SRL chemicals, Mumbai, India, respectively. All chemicals and buffers used were of analytical grade.

\section{Methods}

Selection of liquid proportions for spherical agglomeration

A typical spherical agglomeration process requires a good solvent, a poor solvent for a drug, and a bridging liquid. ${ }^{3}$ The selection of these solvents depends on the miscibility of the solvents and solubility of the ibuprofen in individual solvents. A ternary phase diagram of DMSO, dichloromethane, and water was constructed to select a suitable zone with an appropriate ratio of the three solvents for the preparation of spherical agglomerates.

\section{Effect of amount of bridging liquid on agglomeration}

A bridging liquid is used to cause spherical agglomeration. It should be capable of wetting the particle surface so as to form liquid bridges and dissolving the sample particles.12 Hence, the bridging liquid exerts marked influence on the yield and rate of agglomeration as well as on the strength of the resulting agglomerates. The rate determining step in spherical agglomeration is when the bridging liquid is squeezed out of the pores of the initial flocs, and later transformed into small aggregates or spherical crystals. Accordingly, the amount of bridging liquid used is one of the critical operating variables. ${ }^{12}$ The amounts of solvents selected from the ternary diagram were further modified and studied for influence of the bridging liquid on the process and product. The effect of the type of bridging liquid on agglomeration was seen using dichloromethane, chloroform, and cyclohexane as bridging liquids.

\section{Effect of mode of addition of bridging liquid on the agglomeration}

To investigate the effect of the mode of addition of bridging liquid, the bridging liquid was added dropwise and the as the whole amount, separately. ${ }^{12}$

\section{Effect of agitation speed of the system on agglomeration}

The impact of agitation speeds of $300 \pm 25,500 \pm 25$, and $700 \pm 25 \mathrm{rpm}$ was observed on the preparation of spherical agglomeration of ibuprofen. ${ }^{12}$

\section{Effect of agitation time of the system on agglomeration}

The impact of agitation times of $20 \mathrm{~min}, 30 \mathrm{~min}$, and $60 \mathrm{~min}$ was observed on the preparation of spherical agglomeration of ibuprofen. ${ }^{12}$

\section{Effect of temperature on agglomeration}

The effect of different temperatures on the formation of spherical agglomerates of ibuprofen was observed at $20 \pm 5^{\circ} \mathrm{C}$, $40 \pm 5^{\circ} \mathrm{C}$, and $60 \pm 5^{\circ} \mathrm{C} .^{12}$

\section{Preparation of ibuprofen agglomerates}

Ibuprofen $\left(4 \mathrm{~g}\right.$ ) was dissolved in $30 \mathrm{~mL}$ of DMSO at $40^{\circ} \mathrm{C}$ and the solution was added to $57.5 \mathrm{~mL}$ of water, which was maintained at $20^{\circ} \mathrm{C}$ under continuous stirring at $500 \mathrm{rpm}$ with a propeller on a mechanical stirrer. When fine crystals of ibuprofen began to precipitate, $12.5 \mathrm{~mL}$ of dichloromethane (bridging liquid) was slowly added dropwise. After $30 \mathrm{~min}$ of stirring, agglomerates thus obtained were separated by filtration and dried. The dried agglomerates were then stored in a screw-capped jar in a desiccator. ${ }^{13,14}$

\section{Determination of drug content}

Spherical agglomerates $(50 \mathrm{mg}$ ) were triturated and dissolved in $250 \mathrm{~mL}$ of phosphate buffer $\mathrm{pH}$ 7.2. The solution was then 
filtered. After suitable dilution with phosphate buffer $\mathrm{pH} 7.2$, the solution was analyzed spectrophotometrically (1601 A, Shimadzu corporation, Kyoto, Japan) at $221 \mathrm{~nm} .^{15}$

\section{Determination of melting point}

The melting point of ibuprofen agglomerates were determined by placing the drug-filled capillary tubes in digital melting point apparatus (CDMP-300, Contech Instruments Ltd., Mumbai, India) and the melting point was noted (triplicates) and compared with the pure drug. ${ }^{16}$

\section{Scanning electron microscopy (SEM) studie}

The morphology of agglomerates was examined using a SEM (LEO 440I, Cambridge, England) operating at $15 \mathrm{KV}$. ${ }^{16}$

\section{Fourier transform infrared spectroscopy (FTIR)}

FTIR spectral measurements were taken at ambient temperature using a Perkin Elmer Model 1600 (Minneapolis, Minnesota, USA). Samples were dispersed in $\mathrm{KBr}$ powder and the pellets were made by applying 5-ton pressure. FTIR spectra were obtained through powder diffuse reflectance on the FTIR spectrophotometer ${ }^{17,18}$

\section{Differential scanning calorimetric (DSC) studies}

DSC (DSC-60, Shimadzu Corporation, Kyoto, Japan) studies were performed to authenticate the formation of the spherical crystals or agglomerates. DSC was used after calibration with indium and lead standards, and samples of the crystals (3-5 $\mathrm{mg}$ ) were heated (range $30-200^{\circ} \mathrm{C}$ ) at $10^{\circ} \mathrm{C} / \mathrm{min}$ in crimped aluminium pans under a nitrogen atmosphere. The enthalpy of fusion and melting point were automatically calculated. ${ }^{17,18}$

\section{$X$-ray powder diffraction studies}

$X$-ray powder diffraction patterns were obtained at room temperature using a Philips X' pert MPD diffractometer, with $\mathrm{Cu}$ as the anode material and graphite monochromator, operated at a voltage of $40 \mathrm{Ma}, 45 \mathrm{Kv}$. The process parameters used were set as scan step size of $0.0170(2 \theta){ }^{17,18}$

\section{Micromeritic properties}

\section{Determination of angle of repose}

The flow properties of the powder were evaluated by determining the static angle of repose. This was measured according to the fixed funnel and free-standing cone method. ${ }^{19}$ A funnel with the end of the stem cut perpendicular to the axis of symmetry was secured with its tip $2.5 \mathrm{~cm}$ above graph paper placed on a flat horizontal surface. The powder was carefully poured through the funnel until the apex of the conical pile that formed just reached the tip of the funnel (h). The mean diameter $(D=2 r)$ of the powder cone was determined and the tangent of the angle of repose was given by:

$\theta=\tan ^{-1}(h / r)$

Where, $\theta$ is the repose angle; $h$ is the height; $r$ is the radius. ${ }^{19}$

\section{Measurement of compressibility index}

Flowability of pure and agglomerated samples prepared was also assessed using Carr's index $(\mathrm{Cl})$. The $\mathrm{Cl}$ was calculated from the bulk density and tapped densities. Tapped density was determined by tapping the samples using digital bulk density apparatus (Veego, Mumbai, India). The $\mathrm{Cl}$ was calculated according to the following equation ${ }^{20}$ :

$\mathrm{Cl}(\%)=\left[\left(\rho_{\mathrm{b}}-\rho_{\mathrm{t}}\right) / \rho_{\mathrm{b}}\right] \times 100$

Where, $\rho_{\mathrm{t}}$ is tapped density and $\rho_{\mathrm{b}}$ is bulk density.

In vitro dissolution studies

The dissolution of ibuprofen pure drug and agglomerates were determined using the USP dissolution apparatus type II (Electrolab, Mumbai, India). The dissolution medium used was $900 \mathrm{~mL}$ of gastric simulating fluid without enzymes $(\mathrm{pH}$ 1.2). Five milliliters of sample solution were withdrawn at predetermined time intervals $(10,20,30,40,50$, and $60 \mathrm{~min}$ ) and then filtered through Whatman filter paper No: 40 and the same amount was replaced in the dissolution flask to maintain sink conditions. The amount of dissolved ibuprofen was analyzed spectrophotometrically at $221 \mathrm{~nm} .^{15}$ In vitro dissolution data were statistically analyzed using One-Way ANOVA followed by the Tukey post hoc test for multiple comparisons using Graph Pad Prism. Differences were considered to be significant at a level of $p<0.05$.

\section{In vivo evaluation of agglomerates}

\section{Evaluation of anti-inflammatory activity}

Healthy male albino rats weighing between 150-200 g were used for the study and individually maintained under standard conditions (12-hr light-dark cycles, $25 \pm 2^{\circ} \mathrm{C}$, and $35-60 \%$ humidity). Food and water were available; the animals were fasted overnight before the experiment but they continued to have free water. The experimental protocol was designed and approved by the Institutional Animal Ethics Committee (Reg. No. 557/02/c/ CPCSEA). The animals were divided into three groups, each containing 6 animals. ${ }^{21}$

Group I: Inflammation-induced and vehicle-treated control.

Group II: Inflammation-induced and ibuprofen suspension [20 mg pure ibuprofen in 1\% carboxymethylcellulose (CMC)]administered animals.

Group III: Inflammation-induced and ibuprofen suspension (20 mg ibuprofen agglomerate in 1\% CMC)- administered animals.

The pure ibuprofen suspension (in 1\% CMC) and ibuprofen agglomerate suspension (in 1\% CMC) were given orally. All the animals were treated as per the treatment schedule. After one hour, paw edema was induced by injecting $50 \mu \mathrm{L}$ of $1 \% \mathrm{w} / \mathrm{v}$ carrageenan into the sub planar region of the left hind paw. Paw volume was determined after one hour in all groups. Using a digital plethysmometer (PLM-01 plus, Orchid Scientifics, India), percentage inhibition of edema was calculated using the following equation. ${ }^{22,23}$

$\%$ inhibition $=$ (paw volume of control - paw volume of treated $)$ $\times$ 100/paw volume of control.

The anti-inflammatory activity of ibuprofen and ibuprofen spherical agglomerates was statistically analyzed using OneWay ANOVA followed by the Tukey post-hoc test for multiple comparisons using Graph Pad Prism. Differences were considered to be significant at a level of $p<0.05$. 
Assessment of ulcerogenic potential of ibuprofen agglomerates Healthy male albino rats weighing between 150-200 g were used for the study and individually maintained under standard conditions (12-hr light-dark cycles, $25 \pm 2^{\circ} \mathrm{C}$, and $35-60 \%$ humidity). The rats were fed with animal feed pellets and given water ${ }^{24-26}$. The rats were divided into three groups, each containing 6 animals as the control (group I), standard (group II), and test group (group III).

Group I: Vehicle treated control.

Group II: Inflammation-induced and ibuprofen suspension (20 mg pure ibuprofen in $1 \% \mathrm{CMC}$ )-administered animals.

Group III: Inflammation-induced and ibuprofen suspension (20 mg ibuprofen agglomerate in 1\% CMC)- administered animals.

The animals were kept fasting for $48 \mathrm{hr}$ before test, but water was permitted. The pure ibuprofen suspension (in 1\% CMC) and ibuprofen agglomerate suspension (in $1 \% \mathrm{CMC}$ ) were given orally. All the animals were treated as per the treatment schedule. The animals were then sacrificed after 6 hr. ${ }^{25,26}$ The stomachs were isolated and opened along the greater curvature, the mucosa was washed under slow running tap water and the number and size of ulcers was scored as per the method of Rao et al..$^{24}$ The $\mathrm{pH}$ of the stomach contents was determined using broad range $\mathrm{pH}$ paper. ${ }^{27}$

\section{Severity score:}

$0=$ Normal-colored stomach

$0.5=$ Red coloration of stomach

$1=$ Spot ulcer

$1.5=$ Hemorrhagic streaks

2 = Ulcers $\geq 3$ but $\leq 5$

$3=$ Ulcers $>5$

\section{RESULTS AND DISCUSSION}

Selection of solvent proportions of spherical agglomeration

Spherical agglomerates of ibuprofen were prepared using the simple agglomeration technique using a three-solvent system. ${ }^{16,18} \mathrm{~A}$ typical spherical agglomeration system involves a good solvent, a poor solvent for the drug, and a bridging liquid. The selection of these solvents depends on the miscibility of the solvents and solubility of the drug in individual solvents. Accordingly, acetone, DMSO, and octanol were chosen as good solvents for ibuprofen. Water acts as a non-solvent. Dichloromethane, cyclohexane, and chloroform were chosen as bridging liquids. Different combinations were tried using the ternary phase diagram to produce the optimum solvent system. Similar trials were conducted by Saritha et al. ${ }^{16}$ and Maghsoodi and Yari ${ }^{18}$ The drug solubility and mutual miscibility of solvent systems were examined and DMSO, dichloromethane, and water were selected as a good solvent, bridging liquid, and poor solvent, respectively, for the preparation of ibuprofen agglomerates.

\section{Preparation of spherical agglomerates}

To select the best solvent composition, a ternary diagram was envisaged and DMSO: Dichloromethane: Water (30:12.5:57.5) were chosen for the study (Table 1) and (Figure 1).

To optimize ibuprofen spherical agglomeration by DMSO: Dichloromethane: Water system, several parameters were considered: among these, temperature difference between drug solution in DMSO and water, stirring time, stirring speed, and amount of dichloromethane (bridging liquid). A bridging liquid is used to cause spherical agglomeration, the same was stated by Saritha et al..$^{16}$ and Maghsoodi and Yari ${ }^{18}$ and Maghsoodi and Hajipour. ${ }^{28}$ It should be capable of wetting the particle surface so as to form liquid bridges and dissolving the sample particles; the same phenomenon was explained by Xia et al. ${ }^{29} \mathrm{Hence}$, the bridging liquid exerts influence on the yield and rate of agglomeration, as well as the strength of the formed agglomerates. The same mechanism was described by Maghsoodi. ${ }^{30}$

Agglomerates were formed by agitating the crystals in a liquid suspension and adding a bridging liquid, which preferentially wets the crystal surface to cause binding. The addition of a bridging liquid (dichloromethane) promotes the formation of liquid bridges between the drug crystals to form agglomerates. To optimize ibuprofen spherical agglomeration by DMSO/ dichloromethane/water system, other process parameters were considered such as the amount and mode of addition of the bridging liquid, stirring speed and time, and temperature; similar conditions were followed by Saritha et al. ${ }^{16}$ The diameter of agglomerates was found to increase with increasing amounts of bridging liquid in the medium due to excessive bridging liquid on the surface for coalescence. Size of agglomerates

Table 1. Amount of solvents selected from the phase diagram used to prepare agglomerates of ibuprofen

\begin{tabular}{llll} 
DMSO $(\mathrm{mL})$ & Dichloromethane $(\mathrm{mL})$ & Water $(\mathrm{mL})$ & $\%$ of bridging liquid \\
\hline 30 & 12.5 & 57.5 & 12.5 \\
\hline 30 & 30 & 40 & 30 \\
\hline 30 & 15 & 55 & 15 \\
\hline 40 & 10 & 50 & 10 \\
\hline
\end{tabular}

DMSO: Dimethyl sulfoxide

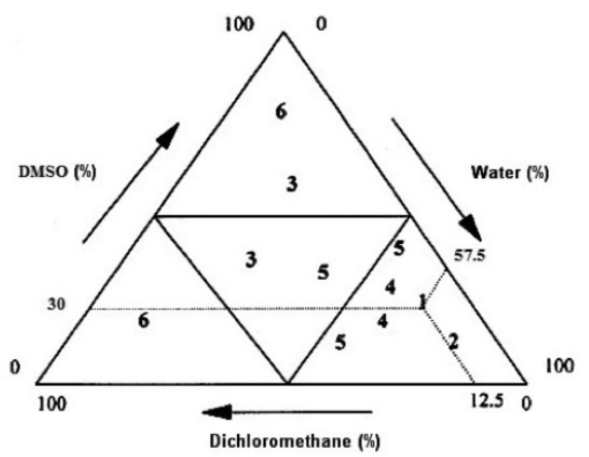

I. Spherical aggiomerates

2. Flocs

3. Suspension

4. Irregular agglomerates

5. Dense suspension with some agglomerates

6. Limpid liquid

Figure 1. Ternary phase diagram of ibuprofen-DMSO/water/DCM DMSO: Dimethyl sulfoxide 
is very much dependent on the degree of agitation because agitation droplets form in the agglomeration medium, which induce movement of the droplets from in to out; the same was reported by Saritha et al. ${ }^{16}$ The intensity of this internal circulation depends on the speed. A lower stirring rate (300 rpm) reduces the possibility of obtaining agglomerates due to the slow circulation of droplets in the medium and slight collision between the droplets; similar procedures were followed by Kulkarni and Subhash Chandra Bose ${ }^{31}$ and Subhash Chandra Bose et al. ${ }^{32}$ At optimum speed (500 rpm), more compact and dense agglomerates were obtained (Table 2). Higher speed (700 rpm) induces agglomerate destruction due to more impact energy for collision because of the increased turbulence resulting in formation of agglomerates with irregular shape; the same results were observed by Bose et al. ${ }^{32}$ Therefore, $500 \mathrm{rpm}$ was selected for the preparation of ibuprofen agglomerates, similarly by Saritha et al. ${ }^{16}$ and Kulkarni and Subhash Chandra Bose. ${ }^{31}$ The temperature of the solvent system was found to have a pronounced effect on the process of agglomeration. Agglomeration was not observed when the process was performed at $20 \pm 5^{\circ} \mathrm{C}$. This could be due to the reduced solubility of the drug in the solvent system. When the temperature was increased to $60 \pm 5^{\circ} \mathrm{C}$, very large agglomerates were produced due to enhanced solubility (saturation of the drug in the medium). Optimum agglomeration was achieved at $40 \pm 5^{\circ} \mathrm{C}$ due to the optimum solubility of the drug. Accordingly, $40 \pm 5^{\circ} \mathrm{C}$ was selected for the preparation of ibuprofen agglomerates; a similar procedure was followed by Kulkarni and Subhash Chandra Bose ${ }^{31}$ and Bose et al. ${ }^{32}$ The addition of a bridging liquid plays a vital role in the formation of agglomerates. When all the bridging liquid was added at one time the agglomerates were of irregular geometry, which may be due to its localization and hence its unavailability for efficient agglomeration; the same theory was reported by Bose et al. ${ }^{32}$ Dropwise addition with continuous agitation resulted in agglomerates of regular geometry, which can be attributed to the uniform distribution of the bridging liquid; the same theory was reported by Bose et al. ${ }^{32}$ Therefore, dropwise addition was selected for the preparation of ibuprofen agglomerates.

From the above study, ibuprofen agglomerates were prepared by using the following conditions:

DMSO: Dichloromethane: Water : 30:12.5:57.5

Table 2. Optimization of process variables for ibuprofen spherical agglomeration

\begin{tabular}{llll} 
S. No & Parameter & Variables & Observations \\
\hline 1 & $\begin{array}{l}\text { Concentration of } \\
\text { bridging liquid } \\
\text { (dichloromethane) }\end{array}$ & $10 \%{ }^{*}$ & No agglomeration \\
\cline { 3 - 4 } & & $12.5 \% *$ & Agglomeration \\
\cline { 3 - 4 } & & $\begin{array}{l}15 \% * \\
20 \mathrm{~min}^{*}\end{array}$ & No agglomeration \\
\hline 2 & Agitation time & $30 \mathrm{~min}^{*}$ & Agglomeration \\
\cline { 3 - 4 } & & $1 \mathrm{hr} \mathrm{min}^{*}$ & Fine particles are formed \\
\hline
\end{tabular}

*At $40^{\circ} \mathrm{C} \pm 5^{\circ} \mathrm{C}, 500 \pm 25 \mathrm{rpm}$ and dropwise addition of bridging liquid
Mode of addition of DCM

Agitation speed

: Dropwise

Agitation time

: $500 \pm 25 \mathrm{rpm}$

Temperature

: $30 \mathrm{~min}$

: $40^{\circ} \mathrm{C} \pm 5^{\circ} \mathrm{C}$

\section{Drug content}

The drug content was determined in triplicate and was found to be in the range of $98.94 \pm 1.73-99 \pm 0.93 \%$.

\section{Melting point}

The melting point of the ibuprofen and spherical agglomerates of ibuprofen were $72^{\circ} \mathrm{C}$ and $71^{\circ} \mathrm{C}$, respectively. No change in the melting points of the pure and prepared agglomerates were observed. Thus, formation of polymorphs was overruled because crystal habit will not change the melting point. Similar findings were reported by Kumar et al. ${ }^{33}$

\section{SEM studies}

The crystal habits and surface features were examined using SEM studies. The pure ibuprofen was in the form of rod-like particles and the agglomerates had round-shaped particles of irregular shape (Figure 2a and $2 \mathrm{~b}$ ). Under high magnification, it was further observed that the surfaces were not smooth and no liquid bridges were found in between two particles. Thus,

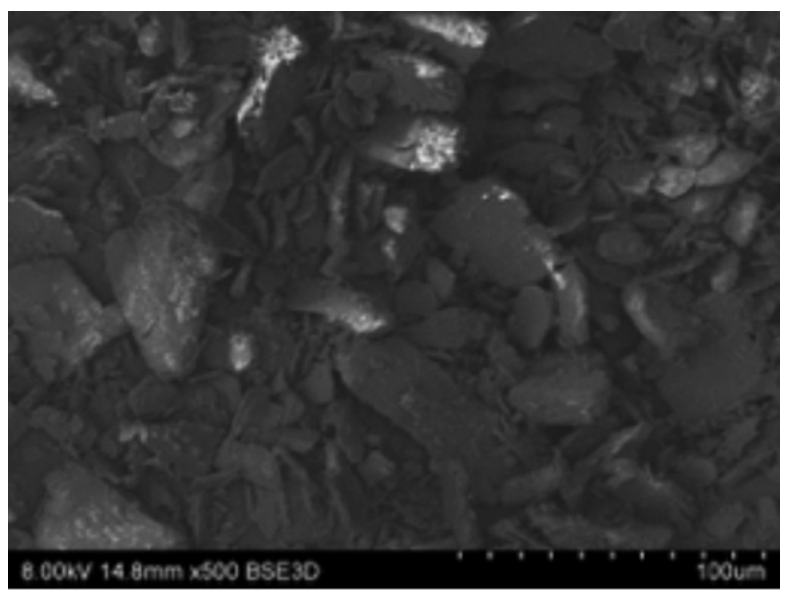

Figure 2a. SEM of pure ibuprofen

SEM: Scanning electron microscopy

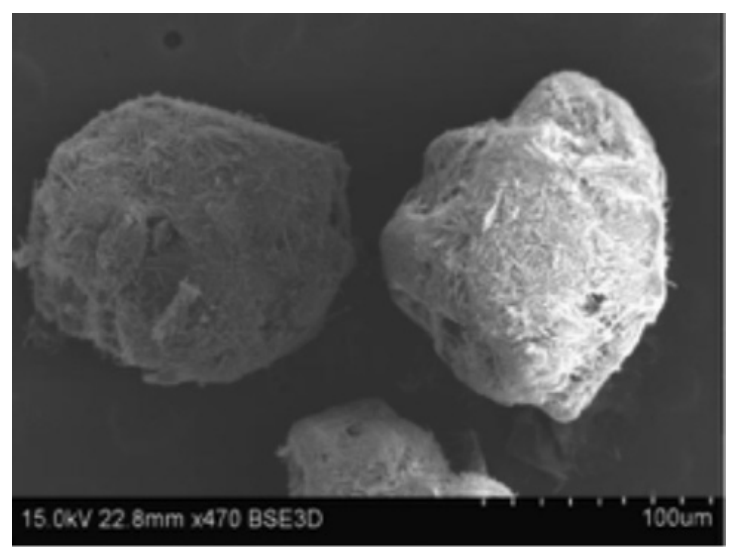

Figure 2 b. SEM of agglomerates

SEM: Scanning electron microscopy 
the produced clusters may be spherical agglomerates. Similar observations were reported by Viswanathan et al..$^{34}$ and Kulkarni and Dixit ${ }^{35}$ who prepared spherical agglomerates of ibuprofen using the neutralization method.

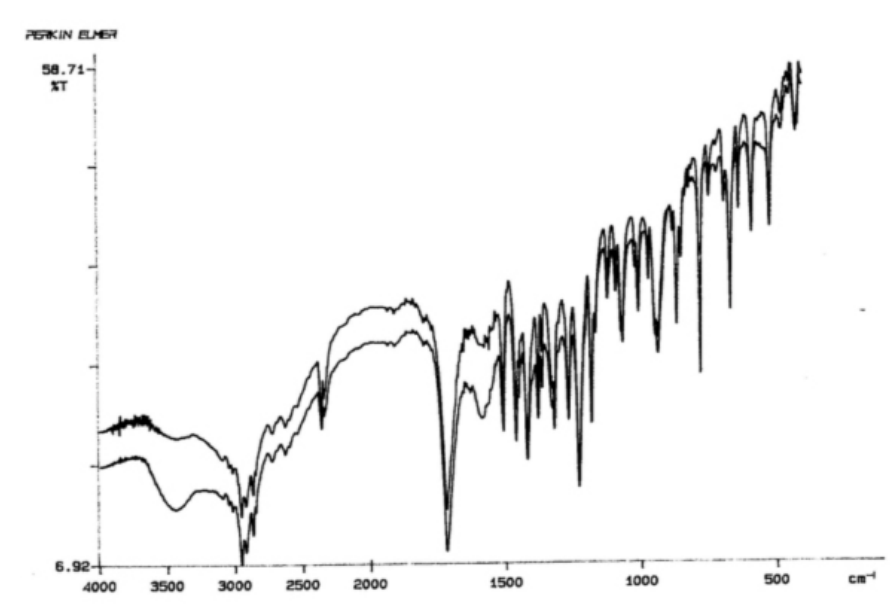

Figure 3. Fourier transform infrared spectroscopy spectra of ibuprofen and its agglomerates

\section{FTIR studies}

FTIR spectra (Figure 3) showed the characteristic absorption peaks of ibuprofen (according to Klaus Florey ${ }^{36}$ ) at $1260\left(\mathrm{CH}_{3}\right.$ stretching vibration), $3000(\mathrm{CO}=\mathrm{OH}$ stretch), 1710-1665 ( $\mathrm{C}=\mathrm{O}$ stretch) and 1600-1585 (C-C stretch) wave numbers, which indicates the presence of alkane, carboxylic, ketone group, and ring structure, respectively, in both pure and agglomerates of ibuprofen; similar findings were observed by Kachrimanis et al. ${ }^{37}$ From the spectral data, it can be concluded that there was not much difference in spectra and absence of polymorphs. Similar observations were reported by Kulkarni et al. ${ }^{38}$

\section{DSC studies}

DSC thermograms of pure and ibuprofen crystals are illustrated in Figure 4. The DSC pattern of pure ibuprofen and agglomerates showed a sharp endothermic peak at $77.51^{\circ} \mathrm{C}$ and $77.80^{\circ} \mathrm{C}$, respectively, corresponding to its melting point. There was a sharp melting point with flat base line, which indicated that the material was not affected by hydration, solvation, and polymorphic transition. In addition, there was no interaction of drug with solvents. Similar observations were reported by Kulkarni and Dixit $^{35}$ and Kulkarni et al. ${ }^{38}$, Kachrimanis et al. ${ }^{37}$, and Pawar et al. ${ }^{39}$

\section{$X$-ray powder diffraction studies}

XRD spectra of the prepared agglomerates showed no significant change in crystal structure and crystal habit when compared with pure ibuprofen. The small differences in the relative intensities of their peaks (Figure $5 a$ and $5 b$ ) at the respective $2 \theta$ values (Table 3 ) may be attributed to differences in the particle size or crystallinity of the sample. Similar observation were reported by Kulkarni and Dixit ${ }^{35}$ and Kulkarni et al. ${ }^{38}$, Pawar et al. ${ }^{39}$, and Rasenack and Muller. ${ }^{40}$ This indicates that ibuprofen

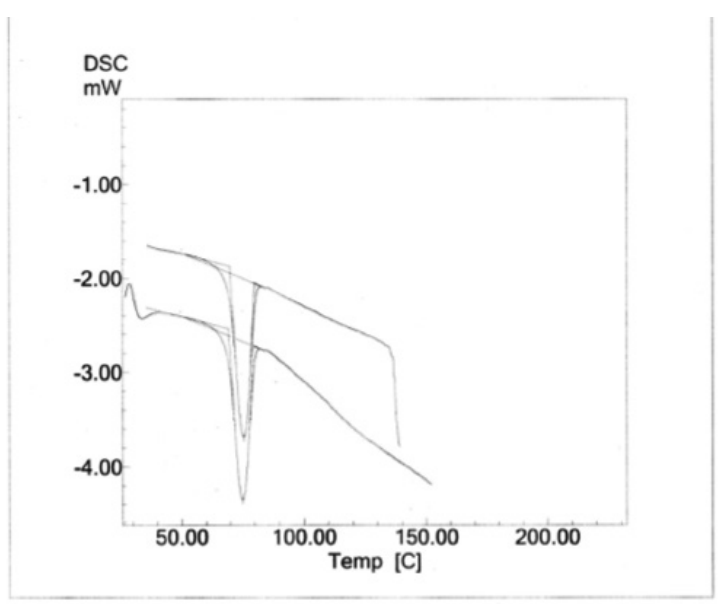

Figure 4. Differential scanning calorimetry thermograms of ibuprofen and its agglomerates

DSC: Differential scanning calorimetry

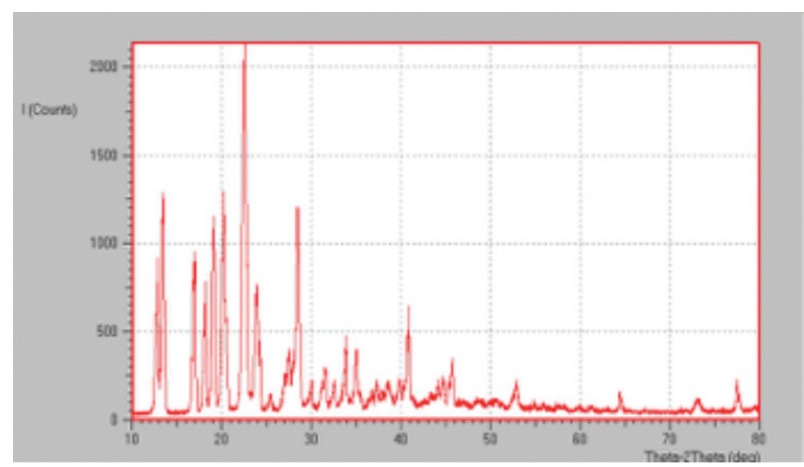

Figure 5a. X-ray diffraction spectra of ibuprofen

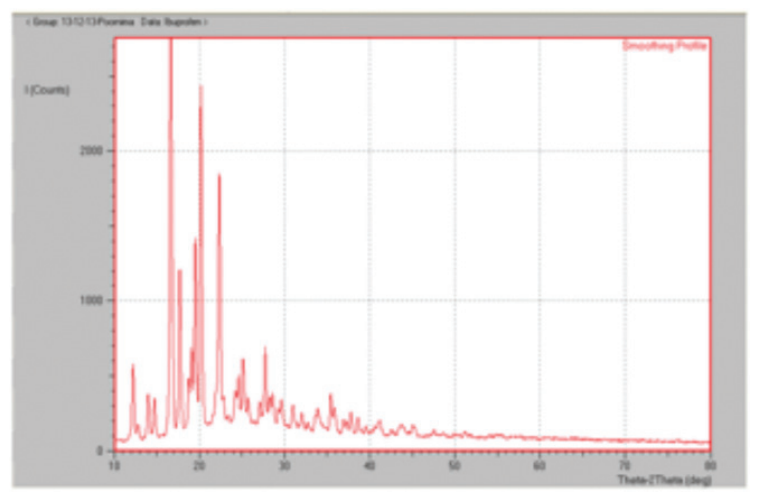

Figure 5b. X-ray diffraction spectra of spherical agglomerates of ibuprofen

does not undergo any polymorphic changes during the process of spherical agglomeration.

\section{Micromeritic properties}

Micromeritic properties such as bulk density, tapped density, angle of repose, and $\mathrm{Cl}$ were determined and shown in Table 4. The bulk and tapped densities of the spherical agglomerates were lower than the corresponding value of the pure sample due to higher particle size and sphericiy. The lower density is likely to be related to the intraparticle porosity and hence 
the reduction in bulk density of the treated samples indicates a greater porosity within the agglomerated particles; similar finding were observed by Maghsoodi ${ }^{30}$ and Gupta et al. ${ }^{41} \mathrm{Cl}$ for agglomerates was found to be lower when compared with the pure drug. This may be due to the formation of agglomerates. Fine particles with high surface to mass ratios are more cohesive than coarser particles, hence more influenced by gravitational force; similar findings were observed by Kumar et al. $^{33}$ and Viswanathan et al. ${ }^{34}$ Decreased values of $\mathrm{Cl}$ for agglomerates have better packability, indicating that they might be suitable for direct tabletting; similar findings were observed by Maghsoodi ${ }^{30}$ and Gupta et al. ${ }^{41}$ The flow properties of the crystals were reflected by the angle of repose. It was found that the angle of repose of the agglomerates was decreased when compared with pure ibuprofen. Such a decreased value indicates improvement in flowability, i.e., free flow of powder mass in comparison with the pure drug; similar findings were observed by Maghsoodi ${ }^{30}$, Kumar et al. ${ }^{33}$, Viswanathan et al. ${ }^{34}$ and Gupta et al. ${ }^{41}$ Flowability of the powder was found to be decreased due to their formation of agglomerates. Here, the value of compressibility and angle of repose represents excellent and good flow of agglomerates, respectively, when compared with that of pure ibuprofen, which has very poor flow.

\section{In vitro dissolution studies of agglomerates}

The release of pure ibuprofen was less than that of ibuprofen agglomerates. The dissolution profile of agglomerates showed a significant $(p<0.05$ ) difference when compared with pure drug. The reason for the faster dissolution may be due to the good wettability of the agglomerates, thus it was easily dissolved in the dissolution fluid, as reported by Jbilou et al. ${ }^{42}$ and Di Martino et al. ${ }^{43}$ Ibuprofen agglomerates showed better dissolution than

Table 3. Comparative values of $2 \theta$ and $D$ values for pure drug and ibuprofen agglomerate

\begin{tabular}{lllll} 
S. No & \multicolumn{3}{c}{ Pure drug } & \multicolumn{2}{l}{ lbuprofen crystals } \\
\cline { 2 - 5 } & Angle $\left(2 \theta^{\circ}\right)$ & D value $\left(\mathrm{A}^{\circ}\right)$ & Angle $\left(2 \theta^{\circ}\right)$ & $\mathrm{D}$ value $\left(\mathrm{A}^{\circ}\right)$ \\
\hline 1. & 12.134 & 7.2877 & 12.222 & 7.23616 \\
\hline 2. & 14.546 & 6.0846 & 14.736 & 6.00634 \\
\hline 3. & 16.503 & 5.3671 & 16.66 & 5.31702 \\
\hline 4. & 17.546 & 5.0503 & 17.705 & 5.00559 \\
\hline 5. & 18.695 & 4.724 & 18.74 & 4.7313 \\
\hline 6. & 19.348 & 4.5838 & 19.52 & 4.5439 \\
\hline
\end{tabular}

Table 4. Micromeritic properties of pure ibuprofen and agglomerates

\begin{tabular}{llllll} 
No Sample & $\begin{array}{l}\text { Bulk } \\
\text { density } \\
\left(\mathrm{g} / \mathrm{cm}^{3}\right)\end{array}$ & $\begin{array}{l}\text { Tapped } \\
\text { densit } \\
\left(\mathrm{g} / \mathrm{cm}^{3}\right)\end{array}$ & $\mathrm{Cl}(\%)$ & $\begin{array}{l}\text { Angle of } \\
\text { repose (\%) }\end{array}$ \\
\hline 1. & Pure ibuprofen & $0.833 \pm 2.31$ & $0.55 \pm 1.9$ & 33.9 & 40.6 \\
\hline 2. $\quad \begin{array}{l}\text { Ibuprofen } \\
\quad \text { Agglomerates }\end{array}$ & $0.641 \pm 1.78$ & $0.588 \pm 2.01$ & 8.26 & 25.1 \\
\hline Cl: Carr's index & & & & \\
\hline
\end{tabular}

the pure drug, which may lead to increased absorption rates and bioavailability, which is well correlated with the findings of Pawar et al..$^{39}$, Jbilou et al. ${ }^{42}$, Di Martino et al. ${ }^{43}$, and Sano et al. ${ }^{44}$ (Figure 6).

\section{Evaluation of anti-inflammatory activity}

Anti-inflammatory activity was tested for pure ibuprofen and agglomerates. Table 5 shows the results of paw edema and percentage inhibition of carrageenan-induced paw edema in rats treated with pure ibuprofen and agglomerates. An extremely significant $(p<0.001)$ inhibition of carrageenan-induced paw edema was observed in animals treated with ibuprofen agglomerates compared with the controls during the entire $5 \mathrm{hr}$ duration of the study. Also, significant ( $p<0.05$ ) inhibition of carrageenan-induced paw edema was observed in animals treated with ibuprofen agglomerates compared with pure ibuprofen during the entire 5-h duration of the study (Table 5). This may be due to the increased dissolution of the agglomerates over pure drug, leading to better absorption and onset of drug action. Also, ibuprofen is a propionic acid derivative, its dissociation constant is 5.3; therefore it is easily absorbed in the acidic $\mathrm{pH}$ of the stomach because it is in an ionised form in acidic $\mathrm{pH}$, as reported by Saritha et al. ${ }^{22}$ Moreover, due to the high wettability of agglomerates, the solubility of agglomerates was increased. Hence, agglomerates showed better anti-inflammatory activity over the pure drug. Therefore, the results of in vivo studies clearly demonstrate that ibuprofen agglomerates show better anti-inflammatory activity over pure drug, thus confirming the better therapeutic efficacy; the same phenomenon was reported by Saritha et al. ${ }^{16}$ and Liles and Flecknell. ${ }^{23}$

An ulcerogenic potential study was performed for pure ibuprofen and agglomerates. Pure ibuprofen produced hemorrhagic steaks with higher intensity than the agglomerates. Pure ibuprofentreated rats' stomachs showed hemorrhagic steaks with high intensity (severity score: 1.5), whereas agglomerate-treated rats' stomachs had red coloration (severity score: 0.5) (Figure 7). No ulcers were observed in the control rats' stomachs. From the ulcerogenic potential study, it can be concluded that ibuprofen agglomerates had improved ulcerogenic potential activity, which may be due to having better absorption and bioavailability than ibuprofen. Similar results were reported by Nagaraju et al. ${ }^{27}$

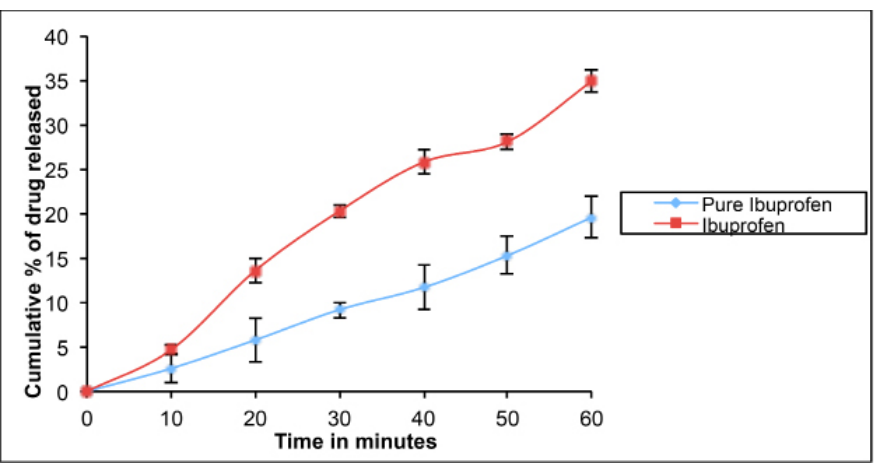

Figure 6. In vitro release profile of ibuprofen and its agglomerates 
Table 5. Anti-inflammatory activity of pure and ibuprofen agglomerates

\begin{tabular}{lllll} 
Group & Treatment & Time $(\mathrm{hr})$ & Paw volume mean & \% inhibition \\
\hline Control & $1 \% \mathrm{CMC}$ suspension & 5 & 0.51 & -- \\
\hline Standard & $20 \mathrm{mg}(100 \mathrm{mg} / \mathrm{Kg})$ pure ibuprofen & 5 & 0.29 & 43.13 \\
\hline Test & $20 \mathrm{mg}(100 \mathrm{mg} / \mathrm{Kg})$ ibuprofen agglomerates & 5 & 0.14 & 72.54 \\
\hline CMC: Carboxymethylcellulose & &
\end{tabular}

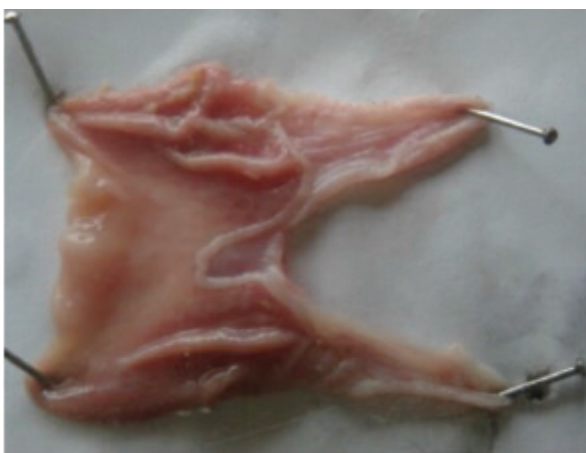

Control

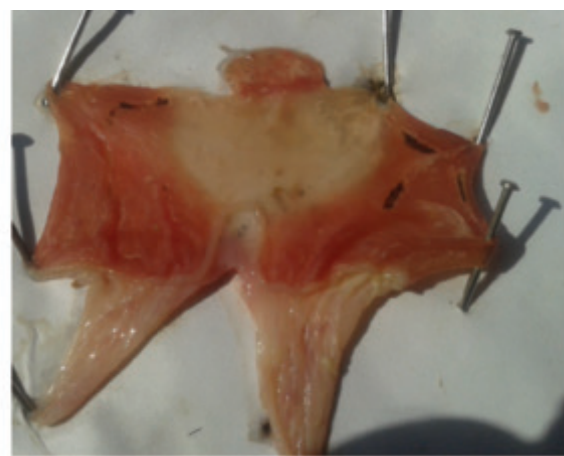

Treated with pure ibuprofen

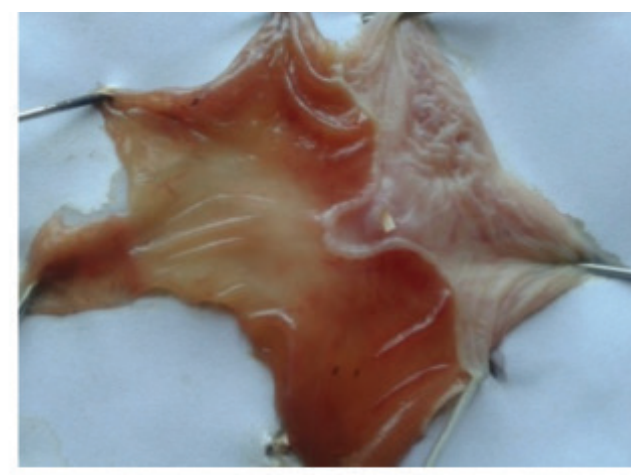

Treated with ibuprofen agglomerates

Figure 7. Photographs of isolated stomach of rats for ulcerogenic potential studies

\section{CONCLUSION}

Ibuprofen agglomerates prepared using the simple spherical crystallization technique exhibited improved micromeritic properties and dissolution rate. FTIR, DSC, and XRD studies showed that there was no change in the crystal structure and polymorphism did not occur. Due to the significant improvement of micromeritic properties, this technique may be used for the formulation of ibuprofen tablets through direct compression. The agglomerates were found have better anti-inflammatory activity in rats when compared with pure drug due to improved solubility.

\section{ACKNOWLEDGEMENTS}

The authors are thankful to Granules India, Hyderabad, India for the gift sample of ibuprofen. We also thank the MNR educational trust and Sri Padmavathi Mahila Visva Vidyalayam for providing necessary facilities to carrying the work.

Conflict of Interest: No conflict of interest was declared by the authors.

\section{REFERENCES}

1. Di Martino P, Di Cristofaro R, Barthelemy C, Joiris E, Palmieri Filippo G, Sante M. Improved compression properties of propyphenazone spherical crystals. Int J Pharm. 2000;197:95-106.

2. Maghsoodi M. How spherical crystallization improves direct tabletting properties: a review. Adv Pharm Bul. 2012;2:253-257.

3. Nokhodchi A, Maghsoodi M. Preparation of spherical crystal agglomerates of naproxen containing disintegrants for direct tablet making by spherical crystallization technique. AAPS PharmSciTech. 2008;9:54-59.

4. Muatlik S, Usha AN, Reddy MS, Ranjith AK, Pandey S. Improved bioavailability of aceclofenac from spherical agglomerates: development, in vitro and preclinical studies. Pak J Pharm Sci. 2007;20:218-226.
5. Gupta VR, Mutalik S, Patel MM, Jani GK. Spherical crystals of celecoxib to improve solubility, dissolution rate and micromeritic properties. Acta Pharm. 2007;57:173-184.

6. Varshosaz J, Tavakoli N, Salamat FA. Enhanced dissolution rate of simvastatin using spherical crystallization technique. Pharm Dev Technol. 2011;16:529-535.

7. Pandey S, Patil AT. Preparation, evaluation and need of spherical crystallization in case of high speed direct tabletting. Curr Drug Deliv. 2014;11:179-190.

8. Kumar S, Chawla G, Bansal AK. Spherical crystallization of mebendazole to improve processability. Pharm Dev Technol. 2008;13:559-568.

9. Maghsoodi M, Hassan-Zadeh D, Barzegar-Jalali M, Nokhodchi A, Martin G. Improved compaction and packing properties of naproxen agglomerated crystals obtained by spherical crystallization technique. Drug Dev Ind Pharm. 2007;33:1216-1224.

10. Thati J, Rasmuson AC. On the mechanisms of formation of spherical agglomerates. Eur J Pharm Sci. 2011;42:365-379.

11. Viswanathan CL, Kulkarni SK, Kolwankar DR. Spherical agglomeration of mefenamic acid and nabumetne to improve micromeritics and solubility: A technical note. AAPS PharmSciTech. 2006;7:48.

12. Paradkar AR, Pawar AP, Chordiya JK, Patil VB, Ketkar AR. Spherical crystallization of celecoxib. Drug Dev Ind Pharm. 2002;28:1213-1220.

13. Katta J, Rasmuson AC. Spherical crystallization of benzoic acid. Int J Pharm. 2008;348:61-69.

14. Kovacic B, Vrecer F, Planinsek O. Spherical crystallization of drugs. Acta Pharm. 2012;62:1-14.

15. Indian Pharmacopoeia, Ministry of Health and Family welfare, The Indian Pharmacopoeia commission, Ghaziabad, 2010:1482.

16. Saritha D, Bose PSC, Reddy PS, Madhuri G, Nagaraju R. Improved dissolution and micromeritic properties of naproxen from spherical agglomerates: preparation, in vitro and in vivo characterization. Braz J Pharm Sci. 2012;48:667-676. 
17. Maghsoodi M, Tajalli Bakhsh AS. Evaluation of physico-mechanical properties of drug-excipients agglomerates obtained by crystallization. Pharm Dev Technol. 2011;16:243-249.

18. Maghsoodi M, Yari Z. Effect of drying phase of the agglomerates prepared by spherical crystallization. Iran J Pharm Res. 2015;14:51-57.

19. Pawar A, Paradkar AR, Kadam SS, Mahadik KR. Effect of polymers on crystallo-co-agglomeration of ibuprofen-paracetamol: Factorial design. Indian J Pharm Sci. 2007;69:658-664.

20. Despande MC, Mahadik KR, Pawar AP, Paradkar AP. Evaluation of spherical crystallization as particle size enlargement technique for aspirin. Indian J Pharm Sci. 1997;59:32-34.

21. Usha AN, Mutalik S, Reddy MS, Ranjith AK, Kushtagi P, Udupa N. Preparation and, in vitro, preclinical and clinical studies of aceclofenac spherical agglomerates. Eur J Pharm Biopharm. 2008;70:674-683.

22. Saritha D, Bose CSP, Nagaraju R. Formulation and evaluation of self emulsifying drug delivery system (SEDDS) of Ibuprofen. Int J Pharm Sci Res. 2014;5:3511-3519.

23. Liles JH, Flecknell PA. The use of non-steroidal anti-inflammatory drugs for the relief of pain in laboratory rodents and rabbits. Lab Anim. 1992;26:241-255.

24. Rao CM, Ramesh KV, Biary KL, Kulkarni DR. Zinc complexes of NSAIDS abolish gastric ulceration propensity of parent drugs. Indian Drugs. 1990;28:64-67.

25. Hussain L, Akash MS, Naseem S, Rehman K, Ahmed KZ. Anti-ulcerogenic effects of salmalia malabarica in gastric ulceration-pilot study. Adv Clin Exp Med. 2015;24:595-605.

26. Rajashekhara N, Ashok BK, Sharma PP, Ravishankar B. Evaluation of acute toxicity and anti-ulcerogenic study of rhizome starch of two source plants of Tugaksheeree (Curcuma angustifolia Roxb. And Maranta arundinacea Linn.). Ayu. 2014;35:433-437.

27. Nagaraju R, Pratusha AP, Subhash Chandra Bose P, Khaza R, Bharathi K. Preparation and evaluation of famotidine polymorphs. Curr Drug Discov Technol. 2010;7:106-116.

28. Maghsoodi M, Hajipour A. Effect of binder liquid type on spherical crystallization. Drug Dev Ind Pharm. 2014:40:1468-1475.

29. Xia D, Ouyang M, Wu JX, Jiang Y, Piao H, Sun S, Zheng L, Rantanen J, Cui F, Yang M. Polymer mediated anti-solvent crystallization of nitrendipine: monodispersed spherical crystallization and growth mechanism. Pharm Res. 2012;29:158-169.

30. Maghsoodi M. Effect of process variables on physicomechanical properties of the agglomerates obtained by spherical crystallization technique. Pharm Dev Technol. 2011;16:474-482.
31. Kulkarni PK, Subhash Chandra Bose P. Spherical agglomeration of nabumetone. Indian J Pharm Educ Res. 2007;41:18-23.

32. Bose CSP, Saritha D, Kumar VM, Kumar Dathrika S. Influence of various bridging liquids on spherical agglomeration of indomethacin. Int $\mathrm{J}$ Res Pharm Sci. 2011;2:147-157.

33. Kumar S, Chawla G, Bansal AK. Spherical crystallization of mebendazole to improve processability. Pharm Dev Technol. 2008;13:559-568.

34. Viswanathan CL, Kulkarni SK, Kolwankar DR. Spherical agglomeration of mefenamic acid and Nabumetone to improve micromeritics and Solubility: A Technical Note. AAPS PharmSciTech. 2006;7:48.

35. Kulkarni P, Dixit M. Preparation and characterization of spherical agglomerates of ibuprofen by neutralization method. Int Res J Pharm. 2010;1:305-313.

36. Florey K. Analytical profiles of drug substances and excipients. 1st ed. Elsevier India; New Delhi; 1984;13:222-224.

37. Kachrimanis K, Nikolakakis I, Malamataris S. Spherical crystal agglomeration of ibuprofen by the solvent-change technique in presence of methacrylic polymers. J Pharm Sci. 2000;89:250-259.

38. Kulkarni PK, Dixit M, Kini AG, Karthik M. Preparation and Characterization of spherical agglomerates of ibuprofen by solvent change method. Scholars Research Library. 2010;2:289-301.

39. Pawar AP, Paradkar AR, Kadam SS, Mahadik KR. Crystallo-coagglomeration: a novel technique to obtain ibuprofen-paracetamol agglomerates. AAPS PharmSciTech. 2004:5:44.

40. Rasenack N, Muller BW. Properties of ibuprofen Crystallized Under Various Conditions: A Comparative Study. Drug Dev Ind Pharm. 2002;28:1077-1089.

41. Gupta VR, Mutalik S, Patel MM, Jani GK. Spherical crystals of celecoxib to improve solubility, dissolution rate and micromeritic properties. Acta Pharm. 2007; 57:173-184.

42. Jbilou M, Ettabia A, Guyot-Hermann AM, Guyot JC. Ibuprofen Agglomerates Preparation by Phase Separation. Drug Dev Ind Pharm. 1999;25:297-305.

43. Di Martino P, Barthelemy C, Piva F, Joiris E, Palmieri GF, Martelli S. Improved dissolution behavior of fenbufen by spherical crystallization. Drug Dev Ind Pharm. 1999;25:1073-1081.

44. Sano A, Kuriki T, Handa T, Takeuchi H, Kawashima Y. Particle design of tolbutamide in the presence of soluble polymer or surfactant by spherical crystallization technique: improvement of dissolution rate. J Pharm Sci. 1987;76:471-474. 